\title{
Environmental factors shaping microbial community structure in salt marsh sediments
}

\author{
Matthew R. First ${ }^{1,2, *}$, James T. Hollibaugh ${ }^{1}$ \\ ${ }^{1}$ Marine Science Building, Department of Marine Science, The University of Georgia, Athens, Georgia 30602-3636, USA \\ ${ }^{2}$ Present address: Woods Hole Oceanographic Institute, Woods Hole, Massachusetts 02543, USA
}

\begin{abstract}
We examined benthic microbial communities in 3 contrasting subtidal salt marsh sediments over the course of a year to investigate the relationship between environmental conditions and benthic microbial community structure. Samples were collected monthly from a high-energy sandy beach, a tidal creek bed, and a Spartina alterniflora marsh border. The concentrations and biomasses of benthic microalgae (BMA), total and potentially active bacteria (measured by an enzyme-activated fluorogenic compound), heterotrophic protists, and metazoan meiofauna were measured at each location. Sediment grain size and porewater $\mathrm{pH}$ explained most of the variability in biomass distributions; variations in benthic biomass did not correlate well with temperature. There was a seasonal shift from a BMA-dominated community in the spring and summer months to bacteria-dominated communities in autumn at all locations, when inactive bacteria were most abundant. When normalized to sediment porewater volume, benthic protists concentrations were not significantly related to sediment porosity. Benthic protist porewater concentrations (mean: $3.4 \times 10^{3}$, range: 0.1 to $9.3 \times$ $10^{3}$ protists $\mathrm{ml}^{-1}$ ) were comparable to protist concentrations in the water column. In contrast, bacteria were several orders of magnitude more concentrated in the sediments (mean: $4.2 \times 10^{9}$; range: 0.6 to $16 \times 10^{9}$ bacteria $\mathrm{ml}^{-1}$ ) than the water column. Low abundances of protists relative to bacteria appear to contribute to long bacterial turnover times, especially in fine-grained sediments. We hypothesize that both grazing by meiofauna and low anaerobic growth efficiency lead to relatively low biomass of bacterivorous protists.
\end{abstract}

KEY WORDS: Marine sediments $\cdot$ Salt marsh $\cdot$ Microzoobenthos $\cdot$ Protists $\cdot$ Bacteria $\cdot$ Biomass

\section{INTRODUCTION}

Salt marsh surficial sediments harbor high microbial biomass and are loci of substantial production by both benthic microalgae (BMA) and microheterotrophs. BMA production in sediments accounts for over onethird of the annual primary production in salt marshes (Gallagher \& Daiber 1974, Sullivan \& Currin 2000). Sediments also receive carbon from the breakdown of salt marsh grasses (Moran \& Hodson 1990) and from particles settling from the water column (Newell 2004). This carbon input provides growth substrate for heterotrophic bacteria and fuels the microbial food web (e.g. Benner et al. 1984). Benthic production is a major component of the overall flux of carbon through salt marshes and near-shore waters. For example, microbenthos (defined here to include bacteria and protists) and metazoan meiofauna are food sources for epibenthic invertebrates, such as shrimp (Zimmerman et al. 2002) and fiddler crabs (Teal 1962). Resuspended BMA (De Jonge \& Van Beusekom 1992, Thoresen 2004) and microheterotrophs (Kreeger \& Newell 2002) are important components in the diet of filter-feeding bivalves.

The quantity of benthic production available to higher trophic levels depends on the microbial community structure and trophic efficiency (i.e. the amount of biomass produced and available to higher trophic levels vs. the amount of carbon respired). Carbon fixed by BMA is rapidly transferred through the benthic food web. In isotope tracer studies, algal- 
derived carbon appeared in meiofauna within $1 \mathrm{~h}$ of the addition of ${ }^{13} \mathrm{C}$ bicarbonate; bacteria incorporated the labeled carbon within several hours (Middelburg et al. 2000). These and other observations suggest that algal-derived carbon is channeled through 2 discrete pathways: (1) directly to herbivorous metazoan meiofauna, or (2) through bacteria to the microbial food web (van Oevelen et al. 2006). However, exchanges between these trophic pathways also occur. For example, diatoms were ingested by both protists and meiofauna (Epstein 1997a) and ingestion of bacteria by meiofauna and microinvertebrates has been observed (Kemp 1987). Additionally, the linkages between bacterivorous microbenthos and meiofauna (Epstein \& Gallagher 1992, Hamels et al. 2001a) indicate that the 2 major routes of carbon flow in benthic environments, at least at times, intersect.

The processes regulating the abundance and activity of bacteria in sediments are especially important as sediment bacteria play a significant role in benthic metabolism and geochemistry by transforming carbon, nitrogen, and sulfur compounds (reviewed by Nealson 1997). Bacteria are several orders of magnitude more concentrated in estuarine sediments than in the water column (Rublee 1982). The relative constancy of total bacteria concentrations (when scaled to porewater volume) suggests that either bottom-up (resource supply) and/or top-down (predation) forces constrain the standing stock of benthic bacteria (Schmidt et al. 1998). The supply of growth substrates (e.g. dissolved organic carbon exuded from BMA) varies with solar irradiance (Smith \& Underwood 1998), and therefore will respond to daily and seasonal cycles. Bacterial production resulting from these inputs must be tempered by loss processes, such as migration out of the sediments, bacterivory, or viral lysis. Viral lysis contributes substantially to prokaryotic mortality in deep-sea sediments (Danovaro et al. 2008). However, in coastal sediments, viruses cause only a minor impact on bacterial mortality (Glud \& Middelboe 2004); the most likely bacterial loss factor within coastal sediments is protist grazing.

In addition to their grazing impact, bacterivorous protists play a key role in overall benthic metabolism by regenerating nutrients (Sherr et al. 1982) and releasing labile organic carbon compounds (Biagini et al. 1998). Bacterivorous protists are a food source for higher trophic levels (e.g. Hamels et al. 2001a). Thus, factors controlling the abundance of heterotrophic protists have implications for trophic efficiency and overall benthic metabolism. Physical and chemical characteristics of the sediments, such as oxygen penetration, can constrain the abundance of protists (Fenchel 1968, Fenchel \& Bernard 1996, Böttcher et al. 2000). Topdown predation and advection or migration out of the system (e.g. Shimeta \& Sisson 1999) may also limit the abundance of heterotrophic protists in sediments.

The seasonal factors (such as temperature, solar input, etc.) that shape physical conditions in the sediment will in turn influence microbial community structure. To understand the relationship between these factors and populations of benthic heterotrophic protists, we characterized benthic microbial community structure (BMA, bacteria, metazoan meiofauna, and heterotrophic protists) in contrasting salt marsh sediments. Samples were collected monthly at 3 locations throughout 2005 and the physical and chemical variables were measured at each site. Seasonal dynamics of benthic populations were then correlated with sediment properties at these sites. Our goals were to test the hypotheses that (1) microbial community structure (defined here as the relative partitioning of biomass among microbenthos and meiofauna) is shaped by environmental conditions, (2) the microbial community response to seasonal changes will be modified by sediment characteristics, and will therefore differ between contrasting sediment types, and (3) the concentration of benthic protists scaled to porewater volume is relatively constant, as has been noted for bacteria (Schmidt et al. 1998).

\section{MATERIALS AND METHODS}

Sampling. Samples were collected at 3 locations on Sapelo Island, Georgia, USA (Table 1). Nannygoat Beach (NB) is a high energy, sandy beach on the southeastern side of this barrier island. Dean Creek (DC) is a tidal creek on the southern end of the island; Samples were collected at locations roughly $2 \mathrm{~km}$ from the creek's mouth. Marsh Landing (ML) is a Spartina

Table 1. Sample sites identifications, locations, and mean physical characteristics of sediment for all sample dates

\begin{tabular}{|c|c|c|c|c|c|c|c|c|}
\hline Location & ID & $\begin{array}{l}\text { Latitude } \\
\qquad\left({ }^{\circ} \mathrm{N}\right)\end{array}$ & $\begin{array}{l}\text { Longitude } \\
\left({ }^{\circ} \mathrm{W}\right)\end{array}$ & $\begin{array}{c}\text { Mean grain } \\
\text { size }(\mu \mathrm{m})\end{array}$ & $\begin{array}{c}\text { Quartile } \\
\text { deviation }(\mu \mathrm{m})\end{array}$ & $\begin{array}{c}\text { Sediment } \\
\text { density }\left(\mathrm{g} \mathrm{cm}^{-3}\right)\end{array}$ & $\begin{array}{l}\text { Water content } \\
\text { (\% wet wt })\end{array}$ & $\begin{array}{l}\text { Organic matter } \\
\text { (\% dry wt) }\end{array}$ \\
\hline Nannygoat Beach & NB & 31.389781 & 81.264107 & 276 & 82 & 1.8 & $23 \pm 2$ & $0.4 \pm 0.1$ \\
\hline Dean Creek & $\mathrm{DC}$ & 31.393084 & 81.270094 & 199 & 56 & 1.1 & $52 \pm 8$ & $5.2 \pm 1.7$ \\
\hline Marsh Landing & ML & 31.417687 & 81.295863 & 148 & 99 & 1.5 & $76 \pm 6$ & $13.1 \pm 2.6$ \\
\hline
\end{tabular}


alterniflora marsh on the landward side of the island, adjacent to a major tidal river. Sapelo Island has a mean daily tidal range of $2.3 \mathrm{~m}$ (data from NOAA). Air temperature and precipitation were recorded at a weather station at the University of Georgia Marine Institute, located within $3 \mathrm{~km}$ of the sample locations. Mean daily air temperature ranged from 2.2 to $31^{\circ} \mathrm{C}$ over the year and $160 \mathrm{~cm}$ of precipitation was recorded (Fig. 1). Sediment samples were collected monthly throughout 2005 (sample dates denoted on Fig. 1) during daylight at low tide when $<0.5 \mathrm{~m}$ of water covered the sediment. Although sampling occurred during both spring and neap tides, the sites were always covered with water when sampled.

At each location, 3 samples ( 200 g each) of the top $1 \mathrm{~cm}$ of sediment were collected with a plastic trowel and placed in clean plastic containers $(0.4 \mathrm{l})$. Sediments were kept at in situ temperature in a water bath incubator until they were either chemically preserved or frozen (within $3 \mathrm{~h}$ of sampling). The sediment sample was mixed with a plastic spatula prior to subdividing and preserving samples. All samples were stored in the dark and frozen (chlorophyll a samples) or refrigerated $\left(4 \pm 2^{\circ} \mathrm{C}\right.$, all other samples) until analysis. Seawater was collected at each station and filtered through a $0.22 \mu \mathrm{m}$ membrane (Poretics). This filtered seawater (FSW) was used to disperse bacteria in water that was isotonic to the sediment porewater.
Sediment temperature was recorded immediately after sample collection. Approximately $2 \mathrm{~g}$ of wet sediment was centrifuged $(10000 \times g$ for $10 \mathrm{~min})$, and the salinity and $\mathrm{pH}$ of the supernatant were determined using a refractometer and a handheld $\mathrm{pH}$ meter, respectively. Sediment density was determined by dispersing $\sim 5 \mathrm{~g}$ of sediment in a graduated cylinder and measuring the weight and water displacement. Sediment porosity was determined by the weight lost after drying for $8 \mathrm{~h}$ (when sediment weight stabilized) at $60^{\circ} \mathrm{C}$.

Percent organic carbon was estimated as weight loss after combusting dried sediments at $550^{\circ} \mathrm{C}$ for $8 \mathrm{~h}$. At each location, a composite grain size analysis was performed by pooling and sieving dried sediment from each monthly sample. Grain size was determined by sieving dried sediments through a series of standard mesh sizes. The mean grain size was calculated from the weight of sediment retained by each sieve. Wellsorted sediments contain grains from a narrow range of size classes while poorly sorted sediments are comprised of grains distributed across a wide range of size classes.

Quantification of benthic microbial communities. The procedures for quantifying components of the benthic microbial community are described in detail elsewhere (First \& Hollibaugh 2008). Briefly, the concentration of benthic microalgae (BMA) was measured

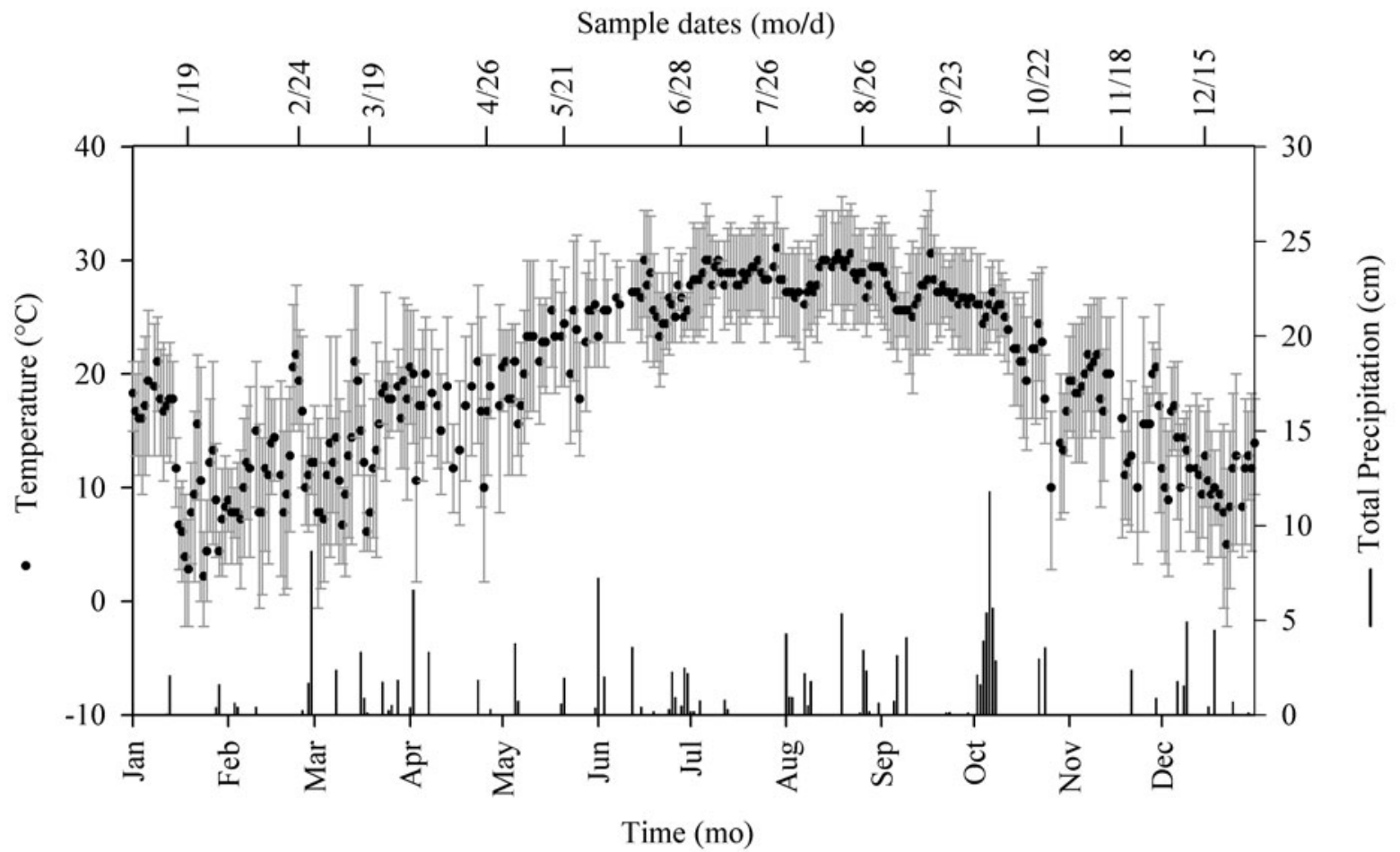

Fig. 1. Air temperature and precipitation recorded at the University of Georgia Marine Institute during the study year 2005. Dots = mean daily air temperature, gray bars = daily temperature range, black bars = precipitation 
by extracting chlorophyll a ( $\mathrm{chl} a$ ) from triplicate sediment samples. The absorbance of the extract was measured with a spectrophotometer and chl a concentrations were calculated by standard spectrophotometric equations for microalgae (Lorenzen 1967). The biomass of BMA was estimated from the ratio of $40 \mu \mathrm{gC}$ : $\mu \mathrm{g}$ chl $a$, derived from diatom-dominated sediments (De Jonge \& Colijn 1994).

The concentrations of both all bacteria (hereinafter 'bacteria') and potentially active bacteria (hereinafter 'CTG+ bacteria') were determined at each sample location. CellTracker ${ }^{\mathrm{TM}}$ Green (chloromethylfluorescein diacetate; CTG, Invitrogen) was used to label CTG+ bacteria (i.e. cells with intact membranes and cytosolic enzymes). Sediment was dispersed in FSW for a $2 \mathrm{~h}$ incubation with CTG. The incubation was stopped by adding glutaraldehyde (4\%, final concentration). Glutaraldehyde-fixed sediment samples were serially diluted in tetrasodium pyrophosphate to disperse particle-attached bacteria (Weinbauer et al. 1998). Bacteria were counted via epifluorescence microscopy. CTG+ cells were counted with no additional stain. The concentration of bacteria (which includes CTG+ and CTG-negative, and thus presumed to be inactive, cells) was determined by staining samples with SYBR Green II (Invitrogen, hereinafter 'SYBR'). The size distribution of SYBR-stained bacteria in each sample was determined by measuring the length and width of images of bacteria captured with a charge-coupled device (CCD) camera using image analysis software (ImagePro Plus 4.1). The biovolume of each cell was calculated from these measurements using published relationships (Bratbak 1985). Biovolume was converted to bacteria biomass using an allometric relationship (Norland 1993). The biomass of bacteria and CTG+ bacteria in each sample was calculated as the product of cell concentration and mean biomass of all bacteria in each sample.

Benthic protists and meiofauna were extracted from preserved sediments using a density gradient created with a colloidal silica solution following published methods (Epstein 1995). The extracted protists were stained with both 4',6-diamidino-2-phenylindole (DAPI) and fluorescein isothiocyanate (FITC), and collected on a $5 \mu \mathrm{m}$ pore size, black polycarbonate filter (Osmonics). Large protists and meiofauna were quantified using epifluorescence microscopy by scanning the entire filter at 100 -fold magnification. Flagellates lacking chloroplasts were counted at 400fold magnification along transects through the filter. Large (>20 $\mu \mathrm{m}$ in equivalent spherical diameter, ESD) heterotrophic protists (mainly ciliates and testate amoebae) were grouped into 15 common morphotypes, with the average size of each morphotype determined from the length and width of $>30$ individ- uals measured with image analysis software. Common ciliates were identified when possible using taxonomic guides (Carey 1992). Flagellates were grouped into 2 size ranges, with average dimensions for each size range based on measurements of $>30$ individuals. Nematodes were grouped into 3 size categories, with the average dimensions based on measurements of 5 to 20 individuals at each location. Individual dimensions were used to calculate biovolume and, in turn, the biomass of protists (Putt \& Stoecker 1989, Wetzel \& Likens 1991) and nematodes (Baguley et al. 2004).

Analysis. The concentrations and biomasses of microbenthos and meiofauna are reported per gram of wet sediment (gws) examined. These quantities can be converted to dry sediment weight (g DSW) or per unit area (of the top $1 \mathrm{~cm}$ of sediment) using the mean porosity and sediment density, respectively (Table 1). Correlations between the biomass of benthic organisms (BMA, bacteria, heterotrophic protists, and meiofauna) and environmental variables (grain size; water temperature; organic matter content; and porewater $\mathrm{pH}$, salinity, and volume) were calculated using the BIO-ENV routine of Primer v5 (Plymouth Marine Laboratory). BIO-ENV determines a single abiotic variable (or combination of variables) that best explains the entire biomass distribution patterns of the benthic organisms (Clarke \& Ainsworth 1993, Clarke \& Warwick 2001). The Julian date of sampling was also considered as an environmental variable to determine if time could impact the biotic community structure. Data sets were normalized as described elsewhere (Clarke \& Gorley 2001). Briefly, a similarity matrix of environmental conditions was normalized by Euclidean distance and the biomass matrix was normalized by

Bray-Curtis similarity. An ordination of the matrices (multidimensional scaling) is performed and the Spearman rank correlation ( $\rho$, ranging from -1 to 1 ) was used to determine the environmental variable (or combination of up to 3 variables) best describing the biomass distributions at all locations.

Protist and bacteria concentrations were adjusted to porewater volume for comparisons with pelagic environments and to determine the relationship between abundance and sediment porosity. The percentage of water weight was converted to water volume using the density of porewater measured at each site. Concentrations (cells $\mathrm{gws}^{-1}$ ) were divided by this water volume to calculate the porewater concentrations (cells $\mathrm{ml}^{-1}$ porewater). Porewater concentrations were log transformed prior to linear regression analysis, which was used to determine the relationship between concentrations and sediment porosity. 


\section{RESULTS}

Although grain size distributions varied over the course of the year at each location, these variations were small relative to the differences in grain sizes between locations (Fig. 2). ML had the smallest mean grain size and had an equal distribution of particles in several size categories, indicating this sediment is poorly sorted. Over $80 \%$ of particles at both DC and NB were 125 to $420 \mu \mathrm{m}$, indicating well-sorted, sandy sediments.

The BIO-ENV analysis relating environmental variables and microbenthos biomass revealed that sediment grain size and porewater $\mathrm{pH}$ explained the most biomass variability ( $\rho=0.628)$. Water temperature (both surface and sediment) explained little of the variability in benthic biomass $(\rho<-0.09)$. Microbenthos or meiofauna biomass were not strongly correlated to surface water or sediment salinity $(\rho=0.186$ and 0.293 , respectively). Julian date was poorly correlated with community structure $(\rho=0.09)$. Combinations of multiple factors (including porosity and organic carbon content) did not improve the correlation between microbenthos biomass and environmental variables. The top 5 variable combinations are reported in Table 2 .

These 3 locations displayed contrasting patterns of both total bacterial and BMA biomass (Fig. 3). The concentration of BMA at DC increased throughout the year to a maximum value of $412 \pm 12$ (mean $\pm \mathrm{SE}$ ) $\mu \mathrm{gC}$

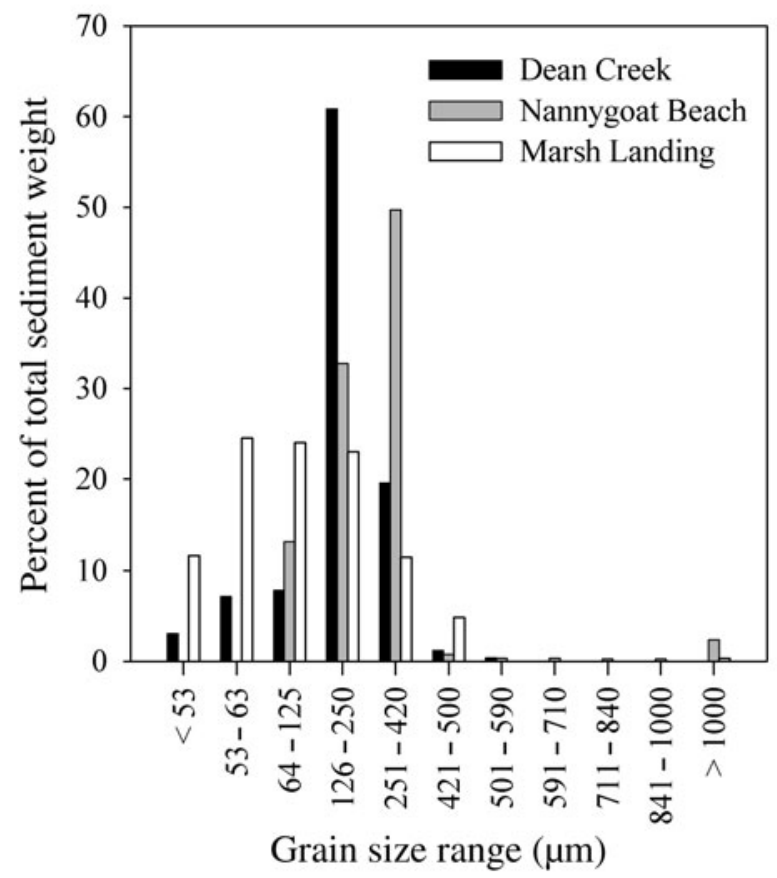

Fig. 2. Grain size distributions at the 3 stations measured on composite samples. See Table 1 for site descriptions
Table 2. Top 5 correlations between combinations of environmental variables and biomass of benthic organisms (shown by Spearman's rank correlation coefficient, $\rho$ ) as determined by the BIO-ENV routine

\begin{tabular}{|lc|}
\hline Variables & $\rho$ \\
\hline Porewater $\mathrm{pH}$, grain size & 0.627 \\
Porewater salinity, porewater $\mathrm{pH}$, grain size & 0.623 \\
Surface water salinity, porewater pH, grain size & 0.593 \\
Surface water pH, porewater $\mathrm{pH}$, organic matter & 0.565 \\
Surface water pH, porewater $\mathrm{pH}$, porosity & 0.561 \\
\hline
\end{tabular}

$\mathrm{gws}^{-1}$ in June (Fig. 3A). BMA biomass was reduced to low concentrations (120 to $170 \mu \mathrm{gC} \mathrm{gws}^{-1}$ ) throughout summer and fall. Conversely, BMA biomass at NB was greatest during winter and spring (Fig. 3B). The highest BMA biomass concentrations at ML were observed in June and November, while concentrations were one order of magnitude lower in April and May (Fig. 3C).

Bacterial biomass at DC increased to a maximum of $253 \pm 16 \mu \mathrm{gC} \mathrm{gws}^{-1}$ in September, when the fraction of CTG+ bacteria reached a minimum (Fig. 3A). The contribution of $\mathrm{CTG}+$ bacteria to total biomass was greatest in NB sediments, where $>70 \%$ of bacteria were CTG+ in 10 of 12 mo (Fig. 3B). Like DC and NB, bacteria concentrations were greatest in September at $\mathrm{ML}$ with the lowest contribution of $\mathrm{CTG}+$ bacteria also occurring in September (Fig. 3C).

Heterotrophic protists were separated into 2 size classes: small protists ranging from 5 to $20 \mu \mathrm{m}$ in length that included mostly heterotrophic flagellates and small scuticociliates; while large heterotrophic protists (>20 $\mu \mathrm{m}$ ) were dominated by ciliates, including representatives of the Classes Spirotrichea (e.g. Aspidisca sp.) and Karyorelictea (e.g. Tracheloraphis sp.). Testate amoebae (ranging from 50 to $300 \mu \mathrm{m}$ in length) were also common at DC. At all locations, nematodes were the dominant group of meiofauna. Harpacticoid copepods and other unidentified microinvertebrates were included in the total meiofauna biomass. Protist biomass at DC followed the BMA trend, where total biomass generally increased from winter to summer (Fig. 4A). The highest biomass at DC was observed in May and July, when large protists were abundant. The large ciliate, Tracheloraphis sp. (mean length, $230 \mu \mathrm{m})$, reached a concentration of $50 \mathrm{gws}^{-1}$ in May. Small protists dominated the biomass at both $\mathrm{NB}$ and $\mathrm{ML}$ during most of the year (Fig. 4B,C).

The total benthic community biomass ranged over nearly 2 orders of magnitude at the locations sampled (Fig. 5). The general trend observed at all locations was a shift from BMA dominance in the early months of the year, to a bacteria-dominated community in the summer and fall months. The contribution of heterotrophic protists to total biomass was greatest at NB 

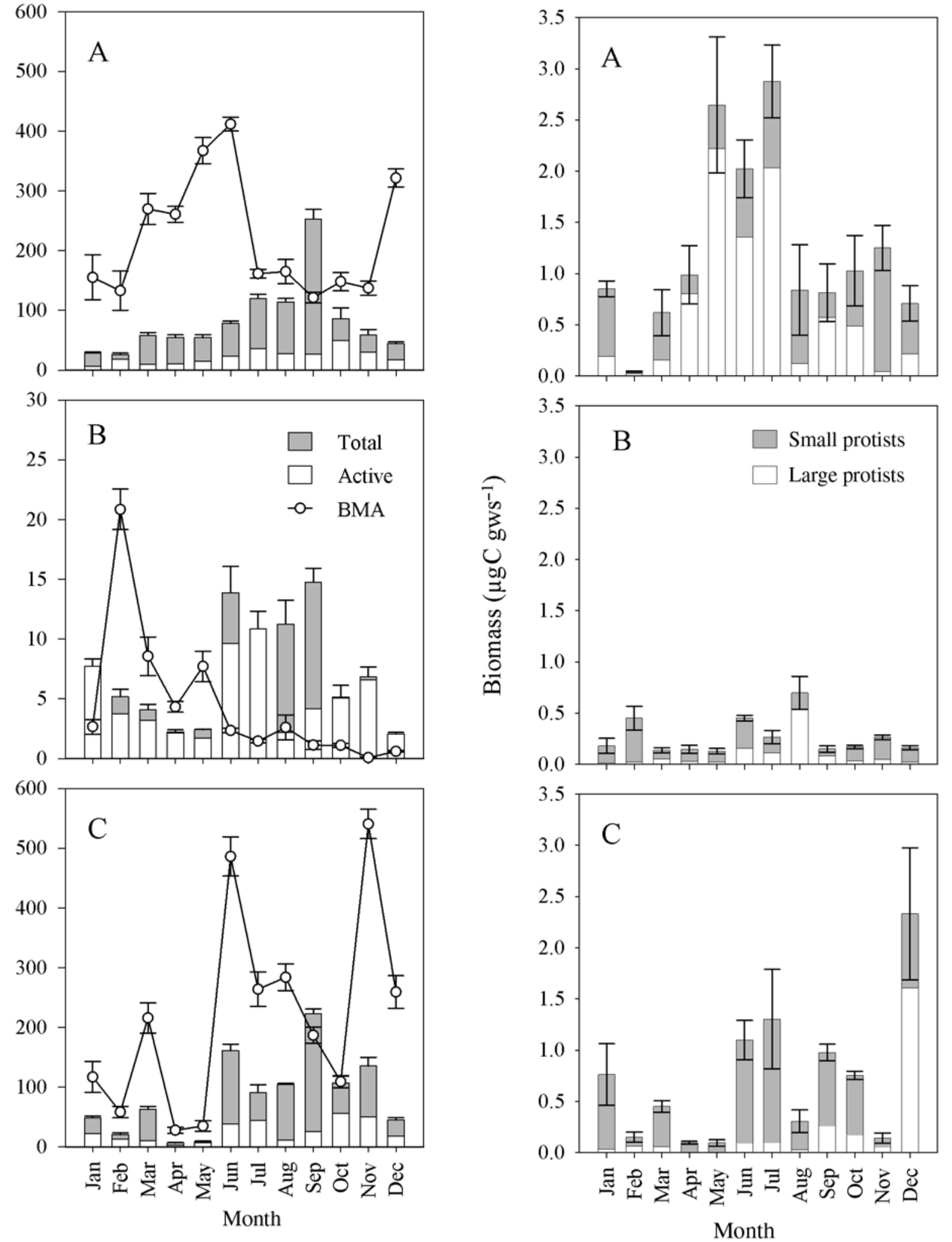

Fig. 3. Bacterial and algal biomass in sediments from (A) Dean Creek, (B) Nannygoat Beach, and (C) Marsh Landing. Bars = mean biomass $(n=3)$ of potentially active and total bacteria with SE bars for the total biomass. Mean benthic microalgal (BMA) biomass (O) with SE bars. gws = gram of wet sediment

Fig. 4. Protist biomass recorded in sediments from (A) Dean Creek, (B) Nannygoat Beach, and (C) Marsh Landing. Bars = mean biomass $(n=3)$ of small $(<20 \mu \mathrm{m})$ and large $(>20 \mu \mathrm{m})$ protists with SE of the combined biomass. gws = gram of wet sediment 
(range, 1 to $6 \%$ of total) and lowest at $\mathrm{ML}(<2 \%)$. The greatest meiofaunal biomass was observed at DC in May (12\% of total biomass). Meiofauna were less than 8 and $2 \%$ of total biomass at NB and ML, respectively.

Protist porewater concentrations ranged from 0.1 to $9.3 \times 10^{3}$ cells ml ${ }^{-1}$ porewater (mean: $3.4 \times 10^{3}$ cells ml $^{-1}$ porewater). Protist abundance normalized to porewater volume (cells $\mathrm{ml}^{-1}$ porewater) showed no significant relationship with sediment porosity (Table 3; Fig. 6A). Concentrations of sediment bacteria ranged from 0.6 to $16 \times 10^{9}$ cells ml ${ }^{-1}$ porewater (mean: $4.2 \times 10^{9} \mathrm{cell} \mathrm{ml}^{-1}$ porewater). Similar to protists, bacterial abundance normalized to porewater volume showed smaller changes with sediment porosity than bulk (cells gws ${ }^{-1}$ ) bacterial abundance (Fig. 6B).

\section{DISCUSSION}

Sediment grain size distributions have profound effects on microbenthos and meiofauna communities (Fenchel 1978). In our study, grain size and porewater $\mathrm{pH}$ were the most significant factors controlling the
Table 3. Linear regression analyses results comparing protist and bacteria concentrations per sediment weight (log cells $\mathrm{gws}^{-1}$ ) and normalized to sediment porewater volume (log cells $\left.\mathrm{ml}^{-1}\right)$. Slope and $y$-intercept values $\pm \mathrm{SE}\left({ }^{*} \mathrm{p}<0.05\right)$. gws = gram of wet sediment

\begin{tabular}{|lcc|}
\hline & log cells $\mathrm{gws}^{-1}$ & $\log$ cells $\mathrm{ml}^{-1}$ \\
\hline Protists & & \\
Slope & $1.0 \pm 0.41^{*}$ & $0.05 \pm 0.42$ \\
$y$-intercept & $2.5 \pm 0.22^{*}$ & $3.3 \pm 0.23$ \\
$\mathrm{R}^{2}$ & 0.16 & 0.00 \\
Bacteria & & \\
Slope & $2.1 \pm 0.25^{*}$ & $1.1 \pm 0.23^{*}$ \\
$y$-intercept & $8.1 \pm 0.13^{*}$ & $8.9 \pm 0.12^{*}$ \\
$\mathrm{R}^{2}$ & 0.69 & 0.42 \\
\hline
\end{tabular}

structure of the benthic microbial community. In a similar system, the abundance of flagellates and their grazing rates on bacteria were also controlled by sediment grain size (Hamels et al. 2001b). Grain size distributions affect the pore space available for the movement of microbenthos. In poorly sorted sediments, the interstitial spaces surrounding large particles are filled by small grains. Advection of water is reduced in the
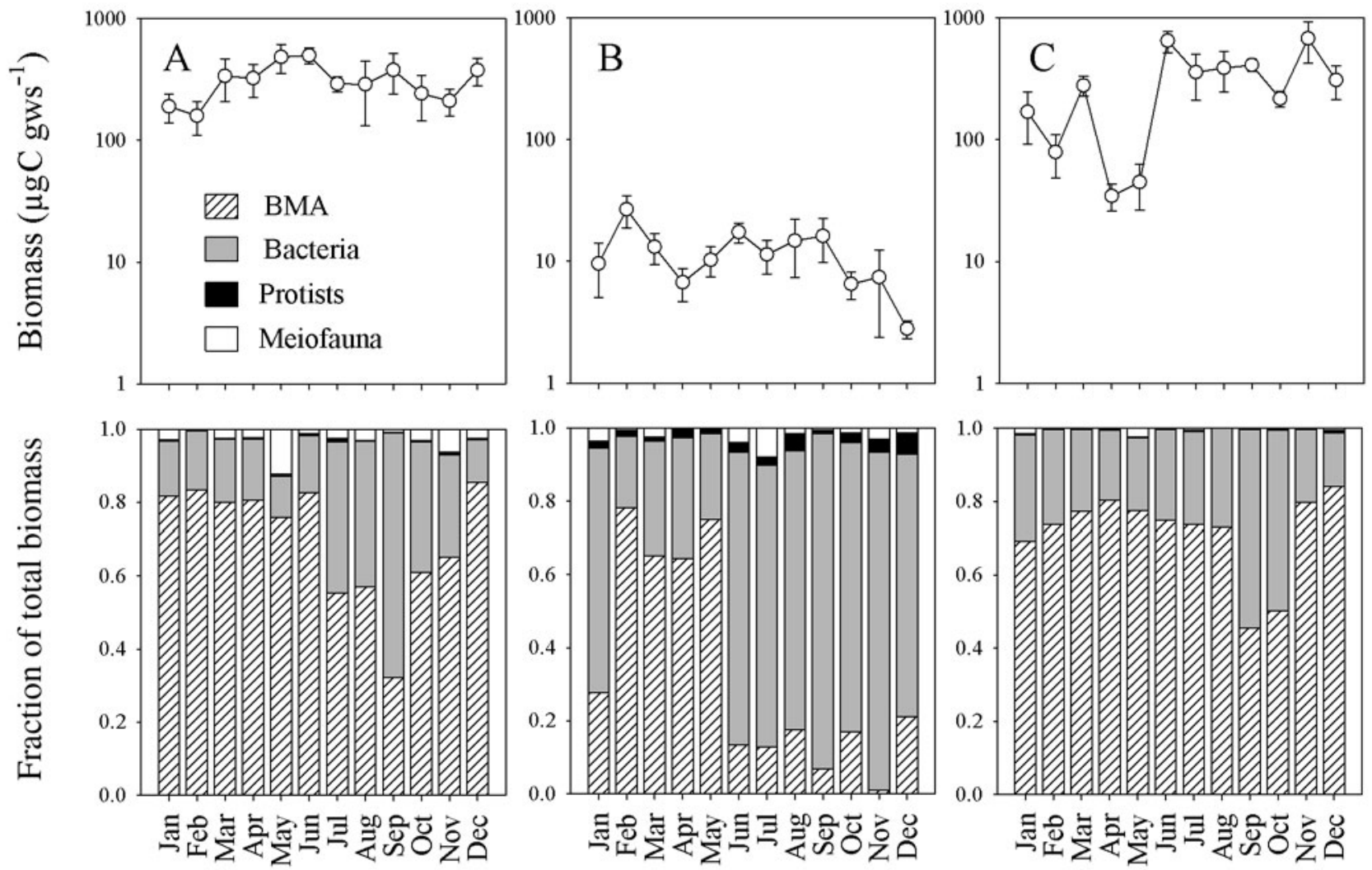

Month

Fig. 5. Total micro- and meiobenthos biomass in sediments from (A) Dean Creek, (B) Nannygoat Beach, and (C) Marsh Landing. Top panels = mean $(n=3)$ total biomass of all groups with SE bars (note the log scale). Bottom panels = contribution of benthic microalgae (BMA), bacteria, protists and meiofauna to the total biomass. gws = gram of wet sediment 

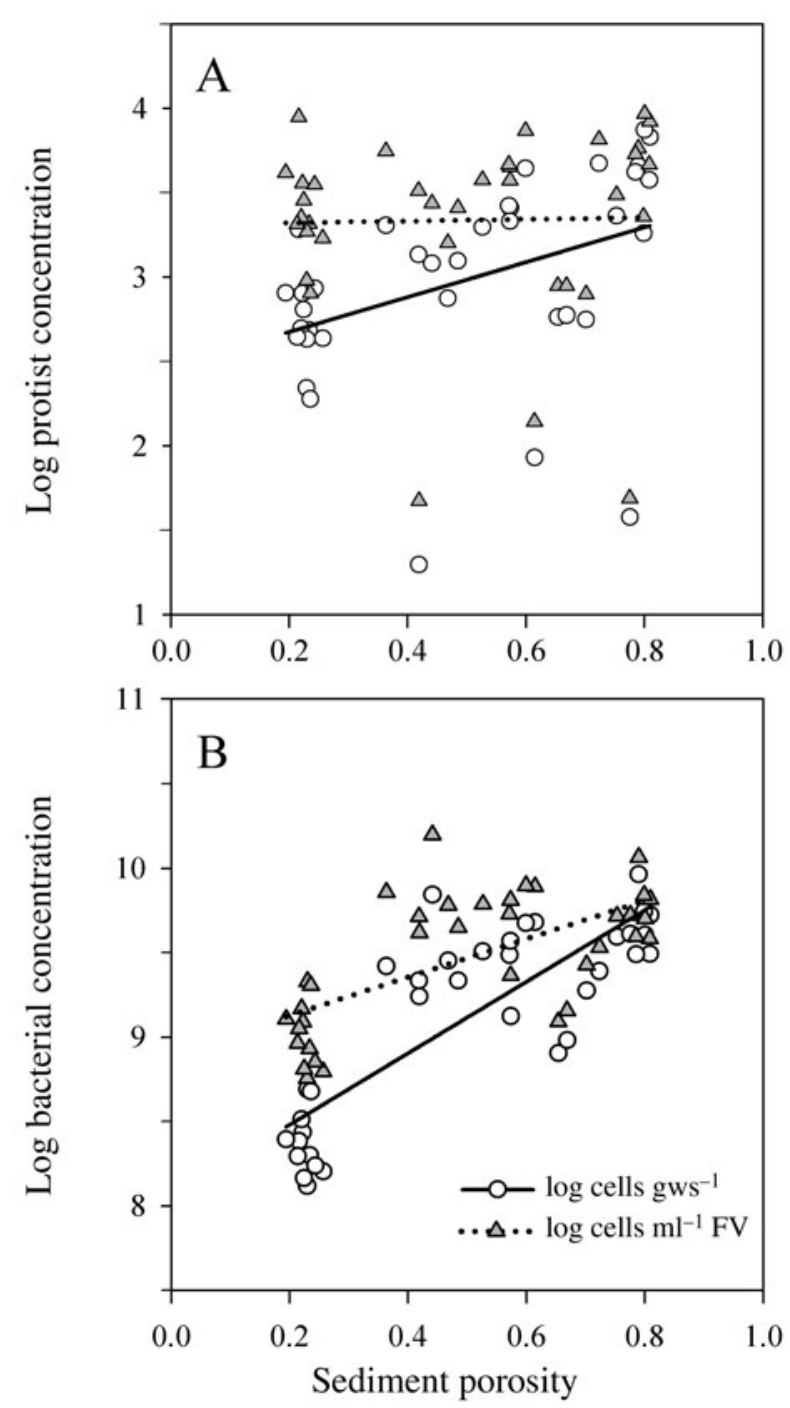

Fig. 6. Relationship between log transformed concentrations of (A) heterotrophic protists, and (B) bacteria and sediment porosity. Concentrations are either unadjusted (cells gws ${ }^{-1}$; gws = gram of wet sediment) or normalized to sediment porewater volume (cells ml ${ }^{-1}$ ). Lines are best fit linear regressions for the unadjusted (solid line) and porewater normalized (dotted line) concentrations. FV = porewater fluid volume

constricted pathways of poorly-sorted, fine-grained sediments. Thus, the flux of dissolved $\mathrm{O}_{2}$ into the sediment and $\mathrm{CO}_{2}$ out of sediments is restricted. This flux partially determines sediment $\mathrm{pH}$ and the depth of the redox boundary zone, which influences the depth distribution of benthic protists (Saburova et al. 2004). Concentrations of $\mathrm{O}_{2}$ and $\mathrm{CO}_{2}$ are also influenced by photosynthesis, which varies due to solar irradiation (Whitney \& Darley 1983) and the structure of the algal community (Pinckney \& Zingmark 1993).

The distribution of benthic organisms was not strongly related to ambient temperature in this study. This is in contrast to other systems in which tempera- ture was critical in shaping the distribution of benthic organisms (Dietrich \& Arndt 2000). Temperature can directly impact the rates of microbial growth and production. Temperature is also a proximal indicator of other seasonal processes that impact sediment production, such as marsh grass production and burial. While the distribution patterns of microbenthos were not dependent upon ambient temperature, seasonal trends were observed and are discussed below.

\section{Seasonal trends}

Total benthic biomass ranges, organic-matter content, and grain-size distributions were very different at the 3 locations. Nevertheless, we observed similar seasonal trends at all locations: BMA dominated microbenthic biomass in spring and early summer, followed by a bacteria-dominated community in late summer and fall. Inactive bacteria composed the majority of bacteria biomass during this time. Protist grazing removes non-growing bacteria and stimulates bacterial activity (Curds 1982, Sherr et al. 1982); therefore, the accumulation of inactive bacteria results from a reduction in protist grazing. Although protist concentrations were lower at some locations during the autumn months, there was no clear relationship between inactive bacteria concentrations and protist abundance.

Fluctuations in BMA abundance may be partially explained by the seasonal impact of epibenthic herbivores, which may be responsible for the decline in BMA concentrations at these locations. Fiddler crabs, for example, have substantial impacts on BMA (Teal 1962). The reduction of BMA abundance in the late summer corresponds to the maximal seasonal abundance of fiddler crabs in similar environments (Mouton \& Felder 1996).

Some of the apparent seasonal variation in BMA biomass could be due to seasonal variation in the carbon:chl a ratio of $\mathrm{BMA}$, as we used this ratio from the literature in our biomass estimates. Because this ratio can fluctuate over seasonal cycles and with shifts in the algal community composition, some of the apparent changes in algal community biomass observed may be due to variation in algal chl a content, which can vary up to $50 \%$ (de Jonge 1980).

\section{Controls on bacterivore abundance}

Concentrations of heterotrophic protists were less variable when normalized to porewater volume than when reported per sediment weight. Porewater protist concentrations were not several orders of magnitude greater than in the water column, as is the case with bacteria (Rublee 1982, Schmidt et al. 1998). Rather, the 
concentrations of heterotrophic protists found were similar to those in pelagic environments $\left(\sim 10^{3}\right.$ cells $\left.\mathrm{ml}^{-1}\right)$. Heterotrophic flagellates are the most abundant bacterivore in pelagic environments (Sherr \& Sherr 2002, and references therein). Flagellates were also the most common heterotrophic protists found in these and other marine sediments (Lee \& Patterson 2002). Water column concentrations of bacteria and heterotrophic flagellates are $\sim 10^{5}$ to $10^{6} \mathrm{ml}^{-1}$ and $10^{2}$ to $10^{4} \mathrm{ml}^{-1}$, respectively (Calbet et al. 2001, Iriarte et al. 2003). Thus, bacteria are proportionally more abundant than heterotrophic protists in these sediments compared to the overlying water column. The regulatory forces driving the high and constant biomass of benthic bacteria have been considered and discussed elsewhere (Schmidt et al. 1998). Here, we discuss the potential mechanisms that regulate the concentration of bacterivorous protists, and how this relates to bacteria standing crop and overall sediment metabolism.

Two processes likely limiting the abundance of benthic bacterivores are (1) low growth efficiencies of protists in anoxic environments, and (2) top-down predation pressure from omnivorous protists and meiofauna. Oxygenated water is advected through sandy, permeable sediments such as those found at NB, and such locations have high rates of aerobic respiration (de Beer et al. 2005). In contrast, oxygen penetration in muddy sediments is limited to the top few millimeters (Böttcher et al. 2000). Our own measurements with DC sediments verify this generalization (M. R. First \& J. T. Hollibaugh unpubl.). Therefore, most of the sediment collected at DC and ML was presumably anoxic. Anoxic environments are known to have truncated food webs due to the low growth yields of fermentation by eukaryotic consumers (Fenchel \& Finlay 1995). In general, there are fewer than 3 trophic levels in anaerobic communities due to the low carbon transfer efficiencies (Fenchel \& Finlay 1990). Furthermore, many metazoans and larger animals are unable to exist for long time periods in anoxic, sulfidic sediments (Fenchel \& Finlay 1995). The large omnivorous protists and meiofauna inhabiting anoxic regions are effectively the top trophic level within the sediments.

In the water column, phagotrophic protists are grazed by both large carnivorous protists and microinvertebrates. For example, omnivorous ciliates depend on the ingestion of flagellates because grazing on bacteria alone cannot support high growth rates for these ciliates (Ohman \& Snyder 1991). Similar topdown controls operate in sediment microbial communities (Epstein \& Gallagher 1992, Hamels et al. 2001a). Large karyorelictid ciliates were abundant throughout the spring and summer months at DC, reaching highest densities in May and June. Many of these ciliates are omnivorous and prey upon flagellates and smaller ciliates (Carey 1992), thus controlling the populations of flagellates and small ciliates that are the major bacterivores. In this case, bacterivorous protists may be the 'missing component' in the diet of large, omnivorous ciliates when grazing on BMA and bacteria is insufficient to support cell growth and maintenance (e.g. Epstein 1997b).

Nematodes may play a significant role in controlling the population of primary bacterivores (i.e. flagellates and small ciliates). Deposit-feeding nematodes ingest particulate organic matter and the resident microbial populations associated with these particles (Sikora \& Sikora 1982, Jensen 1987). The high abundance of nematodes (especially in DC sediments) suggests that the portion of living and detrital biomass processed by nematodes is significant. While bacterivorous protists are relatively scarce compared to benthic bacteria, selective consumption of bacterivorous protists may provide larger metazoan meiofauna, such as nematodes, with a high quality food supply and significant energetic advantage (e.g. Klein Breteler et al. 1999).

Bottom-up factors, such as nutrient supply and organic matter availability, are central to controlling bacterial production. However, bacterial grazers play critical roles in controlling bacterial populations by grazing and regenerating nutrients (Gerlach 1978, Epstein 1997b). The convergence of lower production rates (due to anaerobic metabolism) and high predation pressure on bacterivorous protists (by larger protists and meiofauna) result in conditions where grazing is limited and bacteria standing crops approach theoretical upper limits. Schmidt et al. (1998) suggested that the extraordinarily high abundance of bacteria in mangrove sediments reported by Alongi (1988) may be due to the effective absence of removal processes. In other mangrove sediments, bacterivorous ciliates were too rare to obtain valid estimates of ingestion rates (Kemp 1988). The low growth yield of anaerobic metabolism in these sediments (e.g. Fenchel \& Finlay 1990) may prevent higher protist growth rates and more complete use of the bacterial standing stock. Conversely, in sandy sediments, the advection of oxygenated water permits aerobic respiration deeper in the sediments (de Beer et al. 2005). This leads to extended benthic food webs, lower predation pressure on the primary bacterivores, higher bacterivory rates and, in turn, lower bacteria standing crops.

\section{Implications of high bacteria, low bacterivore concentrations}

Turnover time is the mean time period that an individual bacterium exists in the sediment. Organisms capable of rapid growth have an advantage in systems 
where turnover is rapid. Conversely, slower-growing bacteria are able to accumulate in systems with longer residence times. We used a protist biomass-specific bacteria ingestion rate to calculate turnover times of bacteria at our sampling sites as a heuristic exercise to evaluate the potential range of this emergent property of benthic food webs. The ingestion rate $(0.5$ bacteria $\mu \mathrm{m}^{-3}$ of protist biovolume $\mathrm{h}^{-1}$ ) was determined in another study conducted at the DC site using fluorescently-labeled bacteria (First \& Hollibaugh 2008). The number of bacteria ingested was converted to biomass using the mean biomass per cell, and the hourly grazing rate multiplied by 24 to yield the daily grazing impact $\left(\mu \mathrm{gC} \mathrm{gws}{ }^{-1} \mathrm{~d}^{-1}\right)$. The turnover time of bacteria biomass (d) was then calculated as the bacterial standing stock divided by the daily grazing impact. These calculations do not account for differences in protist feeding rates in different sediment types and we recognize that protist feeding rates likely differ somewhat at each location as a result.

The turnover time varied between the sample dates and locations (Fig. 7). NB consistently had the shortest turnover times (6 to $21 \mathrm{~d}$ ), although a low turnover time was also noted at DC in May. Turnover times were as long as $600 \mathrm{~d}$ (DC, Feb). Estimated turnover times of bacteria at ML were shortest in the summer $(<40 \mathrm{~d})$ and winter months $(<30 \mathrm{~d})$. This exercise demonstrates that the bacteria:protist ratio impacts the bacterial turnover time, assuming feeding rates are relatively similar between locations. The values are consistent with the finding that a majority of bacteria in coastal

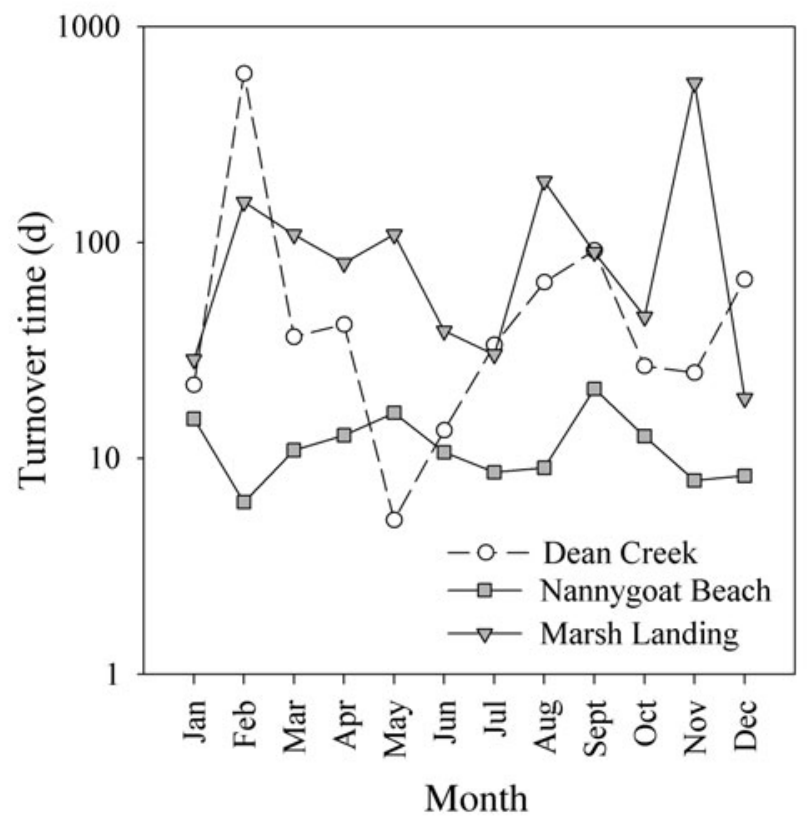

Fig. 7. Mean turnover time (d) of bacteria at all 3 locations over the year sediments, although actively respiring, exhibit low growth rates (Novitsky 1987). Thus, the physical and biological factors that control protist bacterivores (i.e. low anaerobic growth efficiency, predation) result in a high standing stock of inactive bacteria, resulting in reduced rates of organic matter decomposition.

Acknowledgements. This work was supported by NSF Georgia Coastal Ecosystems LTER grant (OCE-9982133). We are grateful for the hospitality and logistical support of J. Garbish and M. Price at the University of Georgia Marine Institute (UGAMI). J. Bernhard, M. Farmer, S. Joye and C. Meile provided guidance on the design of this project and reviewed the manuscript. M.R.F. was supported by a UGA Graduate School Assistantship. We appreciate the comments and suggestion of several anonymous reviewers on an earlier draft of this manuscript. This is contribution no. 967 from UGAMI.

\section{LITERATURE CITED}

Alongi DM (1988) Bacterial productivity and microbial biomass in tropical mangrove sediments. Microb Ecol 15:59-79

Baguley JG, Hyde LJ, Montagna PA (2004) A semi-automated digital microphotographic approach to measure meiofaunal biomass. Limnol Oceanogr Methods 2:181-190

Benner R, Maccubbin AE, Hodson RE (1984) Anaerobic biodegradation of the lignin and polysaccharide components of lignocellulose and synthetic lignin by sediment microflora. Appl Environ Microbiol 47:998-1004

Biagini GA, Finlay BJ, Lloyd D (1998) Protozoan stimulation of anaerobic microbial activity: enhancement of the rate of terminal decomposition of organic matter. FEMS Microbiol Ecol 27:1-8

Böttcher ME, Hespenheide B, Llobet-Brossa E, Beardsley C and others (2000) The biogeochemistry, stable isotope geochemistry, and microbial community structure of a temperate intertidal mudflat: an integrated study. Cont Shelf Res 20:1749-1769

> Bratbak G (1985) Bacterial biovolume and biomass estimations. Appl Environ Microbiol 49:1488-1493

> Calbet A, Landry MR, Nunnery S (2001) Bacteria-flagellate interactions in the microbial food web of the oligotrophic subtropical North Pacific. Aquat Microb Ecol 23:283-292

Carey PG (1992) Marine interstitial ciliates: an illustrated key. Chapman and Hall, Norwell, MA

> Clarke KR, Ainsworth M (1993) A method of linking multivariate community structure to environmental variables. Mar Ecol Prog Ser 92:205-219

Clarke KR, Gorley RN (2001) Primer v5: user manual/tutorial. Primer-E Ltd., Plymouth

Clarke KR, Warwick RM (2001) Change in marine communities: an approach to statistical analysis and interpretation. Primer-E Ltd, Plymouth

Curds CR (1982) The ecology and role of protozoa in aerobic sewage treatment processes. Annu Rev Microbiol 36: $27-46$

> Danovaro R, Dell'Anno A, Corinaldesi C, Magagnini M, Noble R, Tamburini C, Weinbauer M (2008) Major viral impact on the functioning of benthic deep-sea ecosystems. Nature 454:1084-1087

de Beer D, Wenzhöfer F, Ferdelman TG, Boehme SE and others (2005) Transport and mineralization rates in North Sea sandy intertidal sediments, Sylt-Rømø Basin, Wadden Sea. 
Limnol Oceanogr 50:113-127

de Jonge VN (1980) Fluctuations in the organic carbon to chlorophyll a ratios for estuarine benthic diatom populations. Mar Ecol Prog Ser 2:345-353

De Jonge VN, Colijn F (1994) Dynamics of microphytobenthos biomass in the Ems estuary. Mar Ecol Prog Ser 104:185-196

De Jonge VN, Van Beusekom JEE (1992) Contribution of resuspended microphytobenthos to total phytoplankton in the Ems estuary and its possible role for grazers. Neth J Sea Res 30:91-105

> Dietrich D, Arndt H (2000) Biomass partitioning of benthic microbes in a Baltic inlet: relationships between bacteria, algae, heterotrophic flagellates and ciliates. Mar Biol 136:309-322

Epstein SS (1995) Simultaneous enumeration of protozoa and micrometazoa from marine sandy sediments. Aquat Microb Ecol 9:219-227

Epstein SS (1997a) Microbial food webs in marine sediments. I. Trophic interactions and grazing rates in two tidal flat communities. Microb Ecol 34:188-198

Epstein SS (1997b) Microbial food webs in marine sediments. II. Seasonal changes in trophic interactions in a sandy tidal flat community. Microb Ecol 34:199-209

Epstein SS, Gallagher ED (1992) Evidence for facilitation and inhibition of ciliate population-growth by meiofauna and macrofauna on a temperate zone sandflat. J Exp Mar Biol Ecol 155:27-39

Fenchel T (1968) The ecology of marine microbenthos IV. Structure and function of the benthic ecosystem, its chemical and physical factors and the microfauna communities with special reference to ciliated protozoa. Ophelia 6: 1-182

Fenchel TM (1978) Ecology of microbenthos and meiobenthos. Annu Rev Ecol Syst 9:99-121

Fenchel T, Bernard C (1996) Behavioural responses in oxygen gradients of ciliates from microbial mats. Eur J Protistol 32:55-63

Fenchel T, Finlay B (1990) Anaerobic free-living protozoa: growth efficiencies and the structure of anaerobic communities. FEMS Microbiol Ecol 74:269-275

Fenchel T, Finlay BJ (1995) Ecology and evolution in anoxic worlds. Oxford University Press, Oxford

First MR, Hollibaugh JT (2008) Protistan bacterivory and benthic microbial biomass in an intertidal creek mudflat. Mar Ecol Prog Ser 361:59-68

Gallagher JL, Daiber FC (1974) Primary production of edaphic algal communities in a Delaware salt marsh. Limnol Oceanogr 19:390-395

Gerlach SA (1978) Food-chain relationships in subtidal silty sand marine-sediments and role of meiofauna in stimulating bacterial productivity. Oecologia 33:55-69

Glud RN, Middelboe M (2004) Virus and bacteria dynamics of a coastal sediment: implication for benthic carbon cycling. Limnol Oceanogr 49:2073-2081

> Hamels I, Moens T, Mutylaert K, Vyverman W (2001a) Trophic interactions between ciliates and nematodes from an intertidal flat. Aquat Microb Ecol 26:61-72

Hamels I, Muylaert K, Casteleyn G, Vyverman W (2001b) Uncoupling of bacterial production and flagellate grazing in aquatic sediments: a case study from an intertidal flat. Aquat Microb Ecol 25:31-42

Iriarte A, Madariaga I, Revilla M, Sarobe A (2003) Short-term variability in microbial food web dynamics in a shallow tidal estuary. Aquat Microb Ecol 31:145-161

Jensen P (1987) Feeding ecology of free-living aquatic nematodes. Mar Ecol Prog Ser 35:187-196

Kemp PF (1987) Potential impact on bacteria of grazing by a macrofaunal deposit-feeder, and the fate of bacterial production. Mar Ecol Prog Ser 36:151-161

Kemp PF (1988) Bacterivory by benthic ciliates: significance as a carbon source and impact on sediment bacteria. Mar Ecol Prog Ser 49:163-169

Klein Breteler WCM, Schogt N, Baas M, Schouten S, Kraay GW (1999) Trophic upgrading of food quality by protozoans enhancing copepod growth: role of essential lipids. Mar Biol 135:191-198

Kreeger D, Newell R (2002) Trophic complexity between producers and invertebrate consumers in salt marshes. In: Concepts and controversies in tidal marsh Ecology. Kluwer Acedemic Publishers, Dordrecht, p187-220

> Lee WJ, Patterson DJ (2002) Abundance and biomass of heterotrophic flagellates, and factors controlling their abundance and distribution in sediments of Botany Bay. Microb Ecol 43:467-481

Lorenzen CJ (1967) Determination of chlorophyll and pheopigments: spectrophotometric equations. Limnol Oceanogr 12:343-346

Middelburg JJ, Barranguet C, Boschker HTS, Herman PMJ, Moens T, Heip CHR (2000) The fate of intertidal microphytobenthos carbon: an in situ ${ }^{13} \mathrm{C}$-labeling study. Limnol Oceanogr 45:1224-1234

Moran MA, Hodson RE (1990) Contributions of degrading Spartina alterniflora lignocellulose to the dissolved organic-carbon pool of a salt marsh. Mar Ecol Prog Ser 62:161-168

> Mouton EC, Felder DL (1996) Burrow distributions and population estimates for the fiddler crabs Uca spinicarpa and Uca longisignalis in a Gulf of Mexico salt marsh. Estuaries 19:51-61

Nealson KH (1997) Sediment bacteria: Who's there, what are they doing, and what's new? Annu Rev Earth Planet Sci 25:403-434

Newell RIE (2004) Ecosystem influences of natural and cultivated populations of suspension-feeding bivalve molluscs: a review. J Shellfish Res 23:51-61

Norland S (1993) The relationship between biomass and volume of bacteria. In: Kemp PF (ed) Handbook of methods in aquatic microbial ecology. Lewis Publishers, Boca Raton, FL, p 303-307

Novitsky JA (1987) Microbial growth rates and biomass production in a marine sediment: evidence for a very active but mostly nongrowing community. Appl Environ Microbiol 53:2368-2372

Ohman MD, Snyder RA (1991) Growth-kinetics of the omnivorous oligotrich ciliate Strombidium sp. Limnol Oceanogr 36:922-935

Pinckney J, Zingmark RG (1993) Biomass and production of benthic microalgal communities in estuarine habitats. Estuaries 16:887-897

Putt M, Stoecker DK (1989) An experimentally determined carbon-volume ratio for marine oligotrichous ciliates from estuarine and coastal waters. Limnol Oceanogr 34:1097-1103

Rublee PA (1982) Bacteria and microbial distribution in estuarine sediments. In: Kennedy VS (ed) Estuarine comparisons. Academic Press, New York, NY, p 159-182

Saburova MA, Azovskii AI, Polikarpov IG (2004) A comparative analysis of the vertical migrations of interstitial ciliates in different types of sediments. Oceanology (Mosc) 44:535-547

Schmidt JL, Deming JW, Jumars PA, Keil RG (1998) Constancy of bacterial abundance in surficial marine sediments. Limnol Oceanogr 43:976-982

> Sherr EB, Sherr BF (2002) Significance of predation by protists in aquatic microbial food webs. Antonie Leeuwen- 
hoek Int J Gen Mol Microbiol 81:293-308

Sherr BF, Sherr EB, Berman T (1982) Decomposition of organic detritus: a selective role for microflagellate protozoa. Limnol Oceanogr 27:765-769

Shimeta J, Sisson JD (1999) Taxon-specific tidal resuspension of protists into the subtidal benthic boundary layer of a coastal embayment. Mar Ecol Prog Ser 177:51-62

Sikora WB, Sikora JP (1982) Ecological implications of the vertical distribution of meiofauna in salt marsh sediments. In: Kennedy VS (ed) Estuarine comparisons. Academic Press, New York, NY, p 269-282

Smith DJ, Underwood GJC (1998) Exopolymer production by intertidal epipelic diatoms. Limnol Oceanogr 43: 1578-1591

Sullivan MJ, Currin CA (2000) Community structure and functional dynamics of benthic microalgae in salt marshes. In: Weinstein M, Kreeger D (eds) Concepts and controversies in tidal marsh ecology. Kluwer Academic Publishing, Dordrecht, p 81-106

Teal JM (1962) Energy flow in salt marsh ecosystem of Georgia. Ecology 43:614-624

Thoresen M (2004) Temporal and spatial variation in seston

Editorial responsibility: Otto Kinne,

Oldendorf/Luhe, Germany available to oysters and the contribution of benthic diatoms to their diet in the Duplin River, Georgia. PhD dissertation, University of Georgia, Athens, GA

> van Oevelen D, Soetaert K, Middelburg JJ, Herman PMJ and others (2006) Carbon flows through a benthic food web: integrating biomass, isotope and tracer data. J Mar Res 64:453-482

Weinbauer MG, Beckmann C, Höfle MG (1998) Utility of green fluorescent nucleic acid dyes and aluminium oxide membrane filters for rapid epifliuorescencer enumeration of soil and sediment bacteria. Appl Environ Microbiol 64:5000-5003

Wetzel RG, Likens GE (1991) Limnological analysis. Springer Verlag, New York, NY

Whitney DE, Darley WM (1983) Effect of light intensity upon salt marsh benthic microalgal photosynthesis. Mar Biol 75:249-252

Zimmerman R, Minello T, Rozas L (2002) Salt marsh linkages to productivity of penaeid shrimps and blue crabs in the northern Gulf of Mexico. In: Weinstein M, Kreeger D (eds) Concepts and controversies in tidal marsh ecology. Kluwer Academic Publishing, Dordrecht, p 293-314

Submitted: March 16, 2009; Accepted: October 21, 2009 Proofs received from author(s): January 22, 2010 